\title{
Performance Evaluation of a Rice Hull-fueled Cabinet Food Dryer
}

\author{
Jerry B. Guanco', Leomarich F. Casinillo2* \\ 1 Visayas State University, Baybay City, Philippines, \\ https://orcid.org/0000-0002-5150-3447 \\ 2 Visayas State University, Baybay City, Philippines, \\ https://orcid.org/0000-0003-3966-8836 \\ *Email Correspondence: leomarich_casinillo@yahoo.com
}

\begin{abstract}
This study was conducted to determine the technical performance of a rice hull-fueled cabinet food dryer. Data gathered from the drying performance in terms of drying behavior, drying rate, and dryer heat utilization efficiency using cassava chips was analyzed through an experimental design. The study also evaluated fuel consumption, thermal conversion efficiency, energy use efficiency, heat utilization efficiency, temperature distribution and economic performance. Results indicated that the dryer's average fuel consumption and the thermal conversion efficiency is $11.19 \mathrm{~kg} / \mathrm{hr}$ and $6.17 \%$. While the energy use efficiency is $41.51 \%$, and the dryer efficiency is $11.79 \%$. The moisture reduction of the rice hull-fueled dryer is $8.156 \mathrm{~kg} / \mathrm{hr}$, and the heat utilization efficiency is $41.51 \%$. The break-even of using the dryer is $\mathrm{P}$ 4.988/kg; if rented out at $\mathrm{P} 5.86 / \mathrm{hr}$, the payback period is $0.988 \mathrm{batch} / \mathrm{hr}$.
\end{abstract}

Keywords: rice hull, cabinet food dryer, thermal conversion efficiency, energy use efficiency, heat utilization efficiency

\subsection{Introduction}

Industrial dryers are one of the most important equipment in the food processing industries. Most industrial dryers depend on electrical energy and energy from fossil fuel as a source of heat in drying operations (Iranmanesh et al., 2020; Pardhi \& Bhagoria, 2013). Fossil fuel operated dryer is a costly method of operation. It competes in electrical energy and fossil fuel consumption, contributing to undesirable effects on the environment. For these reasons, agricultural waste such as rice hull is an alternative heat source in drying operations. Seemingly, utilizing biomass is both environmentally friendly and economically feasible (Winzer et al., 2017). According to Liu et al. (2017) and Winzer et al. (2017), about $10.3 \%$ of the world's total primary energy is supplied by biomass waste and biofuel. Thus, it is worth noting that rice hull is an abundant waste product. Rice hull has a very peculiar physico-chemical characteristic, and several scientists and engineers investigated its characteristics (Boateng et al., 1992; Gan et al., 2018; Loy et al., 2018). In terms of properties, rice hull has the following: low bulk density (below 150 $\mathrm{kg} / \mathrm{m} 3$ ); low water and moisture permeability; low value of equilibrium moisture content (below $10 \%$ at an air relative humidity $\mathrm{RH}$ of $65 \%$ ); a low value of the coefficient of temperature conductivity 
(below $0.036 \mathrm{~W} / \mathrm{m}-\mathrm{K}$ ); high resistance to the action of harmful fungi; and good anti-corrosion properties to steel aluminum and copper (Valchev et al., 2009). In adition, it is indicated that the bulk density values ranging from $96-160 \mathrm{~kg} / \mathrm{m} 3$ and the hulls can be compressed to $400 \mathrm{~kg} / \mathrm{m} 3$ (Luh, 1980).

Many mechanical dryers developed using agricultural wastes as a heat source to dry agricultural products and improve product storage life (Erbay \& Hepbasli, 2017; Gatea, 2010; Iranmanesh et al., 2020). These dryers are used primarily to reduce the moisture content of a product. Achieving such low moisture content using ordinary sun-drying is very difficult in a relatively humid climate such in the Philippines. Although sun-drying is economical, however, it does not ensure the production of high quality dried products due to intermittent weather condition. Several researchers have proposed using heated air with high airflow to accelerate the drying process and reduce mold incidence (Brennan et al., 1976). The problems observed included; over-drying, non-uniformity of moisture of product being dried and low energy efficiency (Descoteaux \& Savoie, 2003). It is the reason why mechanical dryers should be evaluated first before using them. According to Smith, Sims, and O'Neill (1994), the purpose of evaluating mechanical dryers is to compare their actual performance with the requirements which was developed to achieve the desired efficiency. Determining the mechanical dryer's efficiency and capacity helps in conserving energy and time utilization during the operation. Drying systems have been developed that conserve energy and handling the products gently.

Further study of dryers using heat pumps where sensible and latent heats are recovered from the exhaust air. The heat is then recycled back through the dryer by heating the air entering the dryer using the heat pump condenser (Adapa et al., 2002).
The dryer design and construction make technoeconomically feasible, so one must first consider the thermodynamics of the system (Gatea, 2010; Pardhi \& Bhagoria, 2013). These refer to all heat mass and humidity calculations and then fix the major parameters like the quantity of air required moisture removed from the product, rise and fall of air temperature, and collector dimensions. The mechanical design considerations concentrate on fixing the drying chamber's mechanical details, the perforated sheet, the wire-mesh, and the pressure drop through the dryer.

In this study, an existing rice hull-fueled cabinet food dryer at Philippine Root Crops Research and Training Center (PRCRTC) at Visayas State University (VSU) for drying cassava chips and similar products was evaluated in terms of its technical performance. The study's main objective is to evaluate the technical performance of a rice hull-fueled cabinet food dryer. Specifically, it was conducted to: (1) evaluate the technical performance of the dryer in terms of fuel consumption, thermal conversion efficiency, and temperature distribution inside the dryer; (2) determine the drying performance in terms of drying behavior, drying rate and dryer heat utilization efficiency using cassava chips; and (3) Determine the economic performance of the dryer. This study focused on evaluating the technical and economic performance of an existing rice hullfueled cabinet food dryer. As such, it aims to guide the modification and improvement of the existing cabinet food dryer at PRCRTC. Furthermore, it is also aimed to contribute to the body of knowledge in terms of biosystems engineering and renewable energy.

\subsection{Methodology}

The box-type rice hull-fueled cabinet food dryer used in the experiment is composed of the following main parts: rice hull burner, heat exchanger, suction blowers and the drying 
chamber. A box-type rice hull burner shown in Figure 1 has a $78 \mathrm{~cm} \times 52 \mathrm{~cm} \times 70 \mathrm{~cm}$ dimension. The burner's sidewalls are made of steel plate covered with concrete cement, and the inside part is a sliding grill made of plat bars fastened into burner walls to accommodate the burnt rice hull. The burner is manually operated.

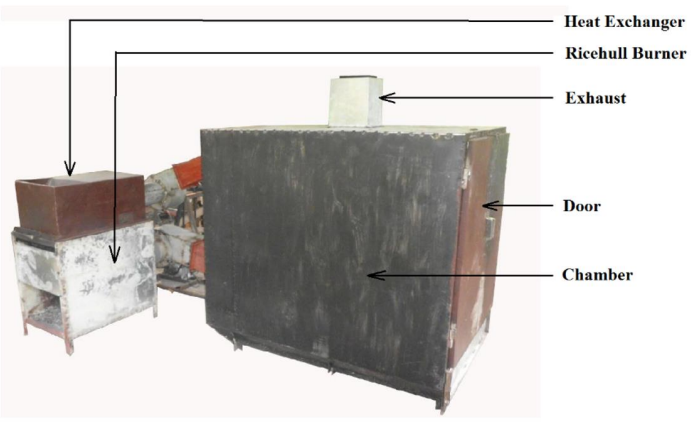

Figure 1. Isometric view (front) of the rice hullfueled cabinet food dryer

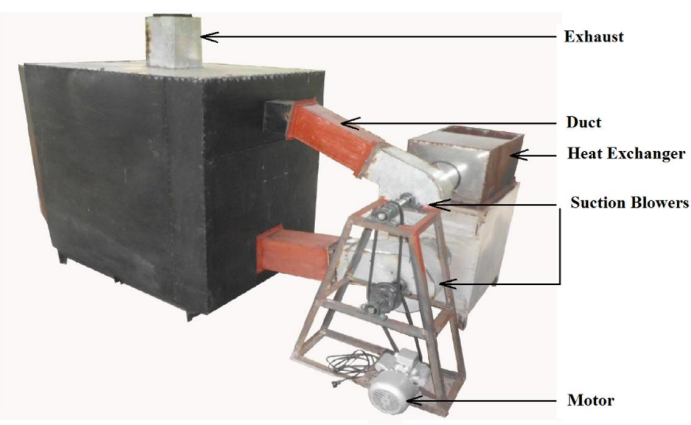

Figure 2. Isometric view (back) of the rice hull-fueled cabinet food dryer

A box type heat exchanger is made of steel plate with a dimension of $70 \mathrm{~cm} \times 44 \mathrm{~cm} \times 35 \mathrm{~cm}$ and located at the upper portion of the rice hull burner as shown in Figure 1. A semi-hopper for the rice hull feeder is a part of the heat exchanger. Small holes located at both sidewalls of the heat exchanger serves as an inlet for clean air. The suction blowers assemble consist of the following: the frame, one electric motor ( $1 \mathrm{hp}$ ), and two suction fans and ducts. These are located at the backside portion of the dryer as shown in Figure 2.

Suction fans are made of steel plate with blades. A cylindrical casing is attached to the blowers' framework assembly. The upper suction blower has a diameter of $25 \mathrm{~cm}$. It conveys clean hot air from the heat exchanger unit and is blown to the drying chamber through the square duct made of steel plate with a dimension of $17 \mathrm{~cm} \times 17 \mathrm{~cm}$. Simultaneously, the lower suction blower has a diameter of $30 \mathrm{~cm}$ and serves to conduct flue gas from the burnt rice hull and blown to the hollow bottom, into the walls of the drying chamber through a square duct with a dimension of $20 \mathrm{~cm}$ $x 20 \mathrm{~cm}$. It is for utilizing the heat generated from flue gas to also heat the drying chamber. The box-type drying chamber is composed of the following: hollow bottom and walls; two flapper doors hinged at the side of the wall to provide an opening in loading and unloading trays; and two separated inlets and exhausts for clean hot air and flue gas, respectively. The inside chamber is made of stainless steel plate with a dimension of $125 \mathrm{~cm}$ $\times 92.5 \mathrm{~cm} \times 120 \mathrm{~cm}$. A total of 12 trays were shelved through the rails attached to the walls; each tray measures $90 \mathrm{~cm} \times 120 \mathrm{~cm}$, as shown in Figure 3 .

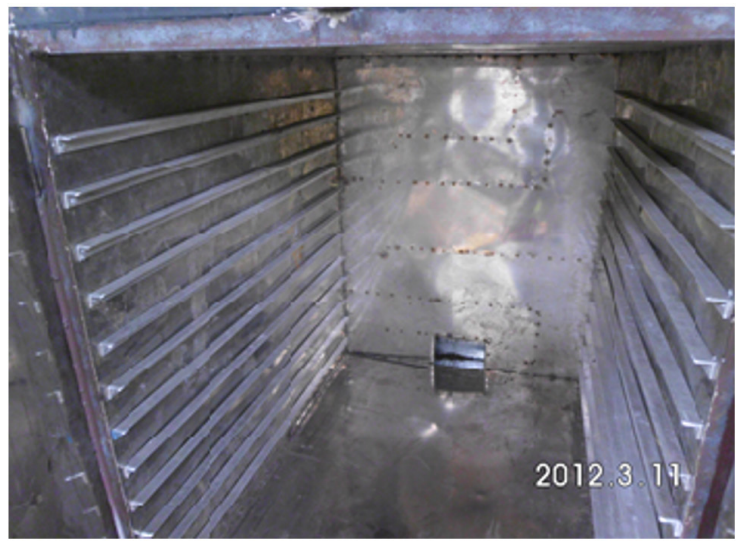

Figure 3. Inside the chamber of the rice hull-fueled dryer 


\section{Operating Principle of the Rice hull-Fueled Dryer}

Preheating was first done to bring the drying chamber's temperature to the desired level while the cassava chips were not yet loaded. It was done by igniting the rice hull to full combustion then both air blowers were turned on to conduct hot air to the drying chamber. Rice hull fuel was fed to the furnace manually at a uniform amount per unit time. A portion of the heat generated in the burnt rice hull was absorbed by clean air through the heat exchanger and sucked by the suction blower, and blown to the drying chamber. In the meantime, another suction blower was installed to suck flue gas from the rice hull burner and blown to heat the drying chamber's bottom and walls. The flue gas was emitted to the exhaust without mixing with the clean and dry hot air.

\section{Preparation of the Cassava Chips}

Cassava roots of the lakan (paramount ruler) variety were used during the evaluation. They were procured from Brgy. Pangasugan, Baybay City, Philippines. These cassava roots were manually washed, peeled and then chipped using a pedaloperated root crop chipper as shown in Figure 4. The chips configuration was of the longitudinal strip form, about 4 to $6 \mathrm{~cm}, 5 \mathrm{~mm}$ thick and $1 \mathrm{~cm}$ wide.

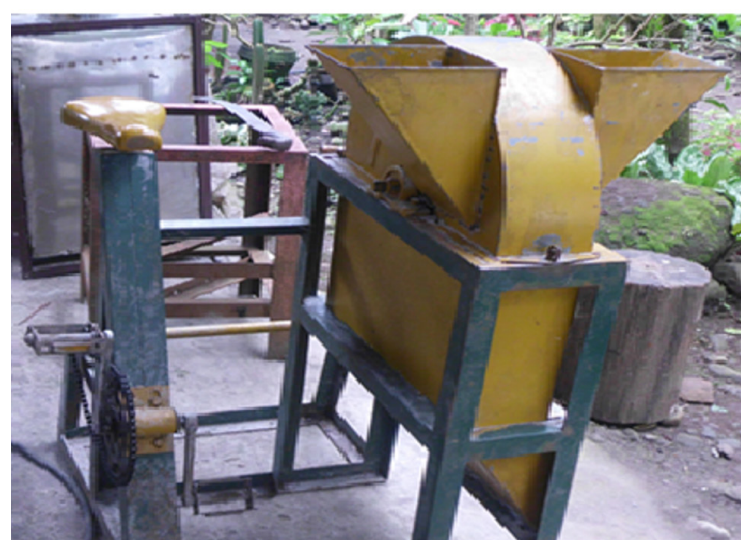

Figure 4. Pedal-operated root crop chipper

\section{Set-up of the Rice Hull-fueled Dryer}

The experiments for evaluating the rice hullfueled dryer's performance were conducted by recording the different drying air properties following the dryer set-up, as shown in Figure 5.

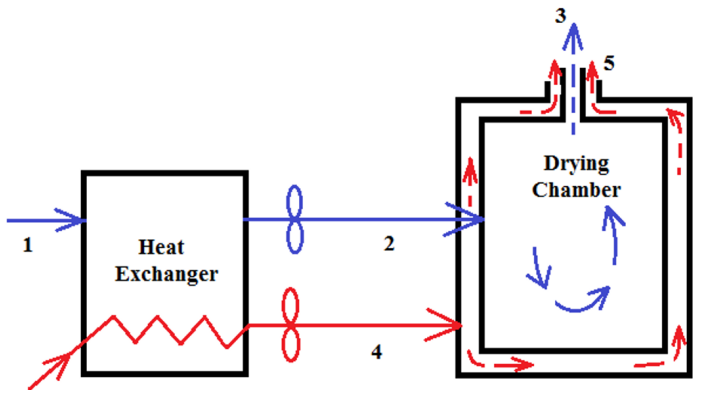

Figure 5. Schematic diagram of the rice hull-fueled dryer set-up

Figure 5 indicates points 1, 2 and 3 ; the ambient air conditions, heated air conditions after passing the heat exchanger, and drying air conditions after passing the dryer, respectively. On the other hand, points 4 and 5 show the conditions of flue gas entering the drying chamber's bottom and side walls from the heat exchanger. This showed the condition of the flue gas that comes out from the drying chamber. Monitoring of drying air properties at different points on the dryer was done every 30 minutes, from the start of the drying operation using thermocouple wires connected to a data logger and computer until the end.

\section{The Drying Experiment}

The drying experiment was conducted using the Randomized Complete Block Design (RCBD) with the trays' position (Top, Middle, and Bottom) as the blocking variable at a constant cassava chip loading density $18 \mathrm{~kg} / \mathrm{m} 2$. In monitoring, the drying five sampling points were identified at the different designated positions (Top, Middle and Bottom) trays, as shown in Figure 6. Each sample's instantaneous weight was monitored every 30 
minutes from the start of drying using a nondestructive sampling method.

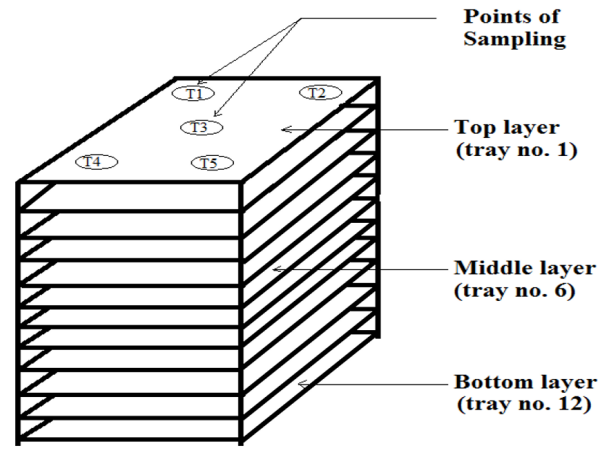

Figure 6. Schematic diagram of the tray levels with different sampling points

Technical Performance Evaluation of the Rice Hullfueled Dryer

This study's technical performance refers to the performance of the rice hull-fueled dryer in terms of average fuel consumption, thermal conversion efficiency, energy use efficiency, heat utilization efficiency, and the drying air temperature distribution inside the dryer. The average fuel consumption was computed using the formula:

$$
\mathrm{FC}=\frac{\mathrm{TFC}}{\mathrm{TD}_{\mathrm{t}}}
$$

Where:

$$
\begin{aligned}
& \mathrm{FC}=\text { Mean Fuel Consumption }(\mathrm{kg} / \mathrm{hr}) \\
& \mathrm{TFC}=\text { Total Fuel Consumption }(\mathrm{kg}) \\
& \mathrm{TD}_{\mathrm{t}}=\text { Total Drying Time (hr) }
\end{aligned}
$$

The heat exchanger's capacity to absorb heat from the fuel was considered the thermal conversion efficiency (TCE) value. It is calculated using the following equation:

$$
\mathrm{TCE}=\frac{\mathrm{m} \Delta \mathrm{h}}{\mathrm{FHv}} \times 100
$$

Where:

$$
\begin{aligned}
& \text { TCE }=\text { thermal conversion efficiency }(\%) \\
& \mathrm{m}=\text { mass flow rate }(\mathrm{kg} / \mathrm{hr}) \\
& \Delta \mathrm{h}=\text { enthalpy change }(\mathrm{kJ} / \mathrm{kg})
\end{aligned}
$$

$$
\begin{aligned}
& \mathrm{Hv}=\text { heating value of fuel }(\mathrm{kJ} / \mathrm{kg}) \\
& \mathrm{F}=\text { fuel consumption rate }(\mathrm{kg} / \mathrm{hr})
\end{aligned}
$$

The heat used in drying based on the heat exchanger was considered the energy use efficiency (EUE) value. It was calculated using the following equation:

$$
\mathrm{EUE}=\frac{\mathrm{E}_{\mathrm{w}} \mathrm{L}}{\mathrm{mh}} \times 100
$$

Where:

$$
\begin{aligned}
& \text { EUE = energy used efficiency }(\%) \\
& E_{w}=\text { rate of water evaporated }(\mathrm{kg} / \mathrm{hr}) \\
& \mathrm{L}=\text { latent heat of vaporization }(\mathrm{kJ} / \mathrm{kg}) \\
& \mathrm{m}=\text { mass flow rate }(\mathrm{kg} / \mathrm{hr}) \\
& \mathrm{h}=\text { enthalpy }(\mathrm{kJ} / \mathrm{kg})
\end{aligned}
$$

The rice hull-fueled dryer heat utilization efficiency refers to the ratio of the actual amount of heat used to evaporate the moisture from the product to the total amount of heat available from the fuel used for drying. It was computed using the formula:

$$
D_{\text {eff }}=\frac{E_{w} l}{F_{c} H v} 100
$$

Where:

$\mathrm{D}_{\text {eff }}=$ Dryer heat utilization efficiency (\%)

$\mathrm{E}_{\mathrm{w}}=$ rate of water evaporation $(\mathrm{kg} / \mathrm{hr})$

$\mathrm{L}=$ Latent heat of vaporization $(\mathrm{kJ} / \mathrm{kg})$

$\mathrm{Hv}=$ Fuel heating value $(\mathrm{kJ} / \mathrm{kg})$

$\mathrm{F}_{\mathrm{c}}=$ Fuel consumption rate $(\mathrm{kg} / \mathrm{hr})$

\section{Drying Performance Evaluation of the Rice Hull- fueled Dryer}

The drying performance used in this study refers to the rice hull-fueled dryer's ability to remove moisture out of the product and how efficiently it utilized energy available for drying. The drying performance was then expressed in terms of the drying behavior, the drying rate, the drying capacity, uniformity of drying, and drying heat utilization efficiency. The drying behavior refers to the instantaneous moisture content plot 
dry basis versus the drying time. It provides the behavior on the removal of moisture content out of the product. The drying rate refers to how fast the moisture is removed from the product per unit time. It was computed using the formula:

$$
D_{r}=\frac{M C_{t}-M C_{(t+\Delta t)}}{\Delta t}
$$

Where:

$\mathrm{D}_{\mathrm{r}}=$ drying rate $\left(\mathrm{g} \mathrm{H}_{2} \mathrm{O} / 100 \mathrm{~g}\right.$ dry matter $)$ $\mathrm{MC}_{\mathrm{t}}=$ moisture content of the product at any time $\mathrm{t}$, dry basis (\%)

$\mathrm{MC}_{(\mathrm{t}+\Delta \mathrm{t})}=$ moisture content of the product at a time interval, dry basis (\%)

$\Delta \mathrm{t}=$ time interval in taking the

instantaneous moisture content (hr)

The drying capacity refers to the total weight of cassava chips placed inside the dryer during the drying process. The uniformity of drying indicates how the values of the instantaneous moisture content of the samples taken at the different locations of the dryer differ from each other.

\section{Economic Performance of the Rice Hull-fueled} Dryer

The dryer's economic performance measures how the rice hull-fueled dryer performs specific economic performance indicators. In this study, the break-even cost (BEC) and payback period were used. The break-even cost was determined using the dryer's fixed cost, the variable cost, and output capacity. It is computed as:

$$
\begin{aligned}
& \mathrm{BEC}=\frac{\mathrm{FC}+\mathrm{VC}}{\mathrm{DCC}}=\frac{\mathrm{TC}}{\mathrm{DCC}} \\
& \text { Where: } \\
& \mathrm{BEC}=\text { break-even cost }(\mathrm{Php} / \mathrm{kg}) \\
& \mathrm{TC}=\text { total cost }=\mathrm{FC}+\mathrm{VC}(\mathrm{Php} / \mathrm{hr}) \\
& \mathrm{FC}=\text { fixed cost }=\mathrm{D}+\mathrm{I}+\mathrm{H}+\mathrm{T}+\mathrm{In}(\mathrm{Php} / \mathrm{hr}) \\
& \mathrm{D}=\text { depreciation cost of dryer }=((\mathrm{PC}- \\
& \mathrm{SV})) / \mathrm{n}(\mathrm{Php} / \mathrm{hr}) \\
& \mathrm{PC}=\text { purchase cost }(\mathrm{Php})
\end{aligned}
$$

$$
\begin{aligned}
& \text { SV = salvage value }(\mathrm{Php}) \\
& \mathrm{n}=\text { probable life }(\mathrm{hr}) \\
& \mathrm{I}=\text { interest }(\mathrm{Php} / \mathrm{hr}) \\
& \mathrm{H}=\text { housing }(\mathrm{Php} / \mathrm{hr}) \\
& \mathrm{T}=\text { taxes }(\mathrm{Php} / \mathrm{hr}) \\
& \text { In = insurance }(\mathrm{Php} / \mathrm{hr}) \\
& \text { VC = variable cost }=\mathrm{F}+\mathrm{L}+\mathrm{M}(\mathrm{Php} / \mathrm{hr}) \\
& \mathrm{F}=\text { fuel }(\mathrm{Php} / \mathrm{hr}) \\
& \mathrm{L}=\text { labor }(\mathrm{Php} / \mathrm{hr}) \\
& \mathrm{M}=\text { maintenance }(\mathrm{Php} / \mathrm{hr}) \\
& \text { DCC = dryer output capacity }(\mathrm{kg} / \mathrm{hr})
\end{aligned}
$$

The payback period as an economic indicator was computed using the formula:

$$
\mathrm{Pp}=\frac{\mathrm{TCD}}{\mathrm{P}}
$$

Where:

$\mathrm{Pp}=$ payback period, batch

$\mathrm{TCD}=$ total cost of the dryer, $\mathrm{Php}$

$\mathrm{P}=$ profit, $\mathrm{Php} / \mathrm{batch}$

\section{Data Gathered}

The following data were gathered during the experiment:

a. Drying Air Condition

These data included the ambient temperature, the temperature in the heat exchanger, the rice hull-fueled dryer entrance, and at different positions (Top, Middle, and Bottom) trays inside the drying chamber, relative humidity of the drying air, and air velocity. The temperature was measured using thermocouples to a data logger connected to a computer. In contrast, the relative humidity and air velocity were measured using a digital all-in-one airflow meter.

b. Fuel Consumption of the Rice Hull-fueled Dryer

These data were gathered by recording the total amount $(\mathrm{kg})$ of rice hull used until drying was stopped. The consumption rate was 
computed by dividing the total weight by the total time.

c. Initial Moisture Content of the Cassava Chips

Before the start of each drying process, the initial moisture content of the product was determined. It was done by oven drying the samples until it reached their bone dry weight. The initial moisture content was computed using the following formula:

$$
\mathrm{MC}_{\mathrm{i}}=\frac{\mathrm{W}_{\mathrm{i}}-\mathrm{W}_{\mathrm{d}}}{\mathrm{W}_{\mathrm{d}}} \times 100
$$

Where;

$$
\mathrm{MC}_{\mathrm{i}}=\text { moisture content, dry basis (\%) }
$$

$\mathrm{W}_{\mathrm{i}}=$ initial moisture content $(\mathrm{g})$

$\mathrm{W}_{\mathrm{d}}=$ final oven-dry weight of the sample

d. Instantaneous Moisture Content of the Cassava Chips

It was determined on a dry-weight basis using the instantaneous weight of the sample using the formula:

$$
\mathrm{MC}_{\mathrm{t}}=\frac{\mathrm{W}_{\mathrm{t}}-\mathrm{W}_{\mathrm{d}}}{\mathrm{W}_{\mathrm{d}}} \times 100
$$

Where;

$\mathrm{MC}_{\mathrm{t}}=$ instantaneous moisture content at time $\mathrm{t}$, dry basis (\%)

$\mathrm{W}_{\mathrm{t}}=$ instantaneous weight of the

samples at time $\mathrm{t}(\mathrm{g})$

$\mathrm{W}_{\mathrm{d}}=$ Oven-dry weight of the samples (g)

e. Fixed Cost and Variable Costs in Operating the Rice hull-Fueled Dryer

The rice hull-fueled dryer's initial cost refers to fixed cost, while the material cost, maintenance cost, labor cost, and operating cost refer to variable cost.

\section{Statistical Analysis}

The data on temperature, instantaneous moisture content, and drying rate is taken from different positions. Layersinside the drying chamber were analyzed using a graphical presentation and variance analysis (ANOVA) following a randomized complete block design (RCBD) with the different levels as the blocking variable. On the other hand, the same data taken at a different point within the same layer were analyzed using the completely randomized design (CRD).

\subsection{Results and Discussion}

\section{Rice hull-Fueled Dryer Test Run}

The dyer test-run was done to check some dryer defects to address its repair and adjustment and get acquainted with the data gathering process. The preheating period and fuel consumption rate per hour were also determined. The preheating period was 60 minutes when the rice hull-fueled dryer attained the temperature required for drying of cassava chips, wherein between $80^{\circ} \mathrm{C}$ to $90^{\circ} \mathrm{C}$. The average fuel consumption rate was found to be 11 to $12 \mathrm{~kg} / \mathrm{hr}$, respectively.

\section{Drying Air Properties}

The actual data gathering on the basic drying air properties such as temperature and relative humidity were done in three (3) trials. The values of ambient, flue gas, drying air, exhaust air temperatures, and relative humidities are summarized in Table 1.

The mean dry bulb temperature and relative humidity of ambient air at point 1 during the drying operation were recorded at $31.9^{\circ} \mathrm{C}$ and $76.2 \%$, respectively. The temperature increased to $210.9^{\circ} \mathrm{C}$ inside the furnace and passed through the heat exchanger. The drying air temperature entering the drying chamber was $76.7^{\circ} \mathrm{C}$ as drawn by the blower to the inside of the drying chamber. Inside the drying chamber, the average temperature was $62.2^{\circ} \mathrm{C}$ and reduced to $58.4^{\circ} \mathrm{C}$ as it moved to the exhaust vent. The ambient air's mean relative humidity ( $(\theta 3)$ was reduced from $76.2 \%$ to $54.4 \%$. The variations of these data concerning time are shown in Figures 7 and 8. 
Table 1. Mean Temperatures $\left({ }^{\circ} \mathrm{C}\right)$ and Relative Humidity (\%)

\begin{tabular}{ccccccccc}
\hline & \multicolumn{3}{c}{ AMBIENT AIR } & \multicolumn{6}{c}{ FLUE GAS } & \multicolumn{5}{c}{ DRYING AIR } \\
\cline { 2 - 9 } TRIAL & $\begin{array}{c}(1) \\
\text { Temp. } \\
\left({ }^{\circ} \mathrm{C}\right)\end{array}$ & $\begin{array}{c}(1) \\
\mathrm{RH},(\%)\end{array}$ & $\begin{array}{c}\text { Temp. } \\
(4)\end{array}$ & $\begin{array}{c}\text { Temp. } \\
\left({ }^{\circ} \mathrm{C}\right)\end{array}$ & $\begin{array}{c}\text { Temp. } \\
\left({ }^{\circ} \mathrm{C}\right)\end{array}$ & $\begin{array}{c}\text { Temp. } \\
\text { w/in } \\
\text { chamber } \\
\left({ }^{\circ} \mathrm{C}\right)\end{array}$ & $\begin{array}{c}\text { Temp. } \\
\left({ }^{\circ} \mathrm{C}\right)\end{array}$ & $\begin{array}{c}(3) \\
\mathrm{RH} \\
(\%)\end{array}$ \\
\hline 1 & 31.6 & 75.9 & 210.8 & 109.13 & 77.8 & 64.6 & 57.4 & 54.2 \\
2 & 31.8 & 76.0 & 211.2 & 110.64 & 76.2 & 62.2 & 58.5 & 54.3 \\
3 & 32.1 & 76.7 & 210.7 & 107.15 & 76.0 & 59.9 & 59.2 & 55.0 \\
Ave. & 31.9 & 76.2 & 210.9 & 108.98 & 76.7 & 62.2 & 58.4 & 54.5 \\
\hline
\end{tabular}

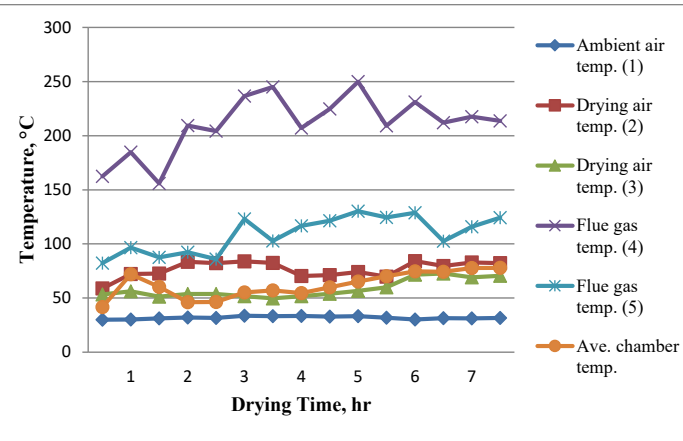

Figure 7. Temperature profile of the different points in the dryer set-up

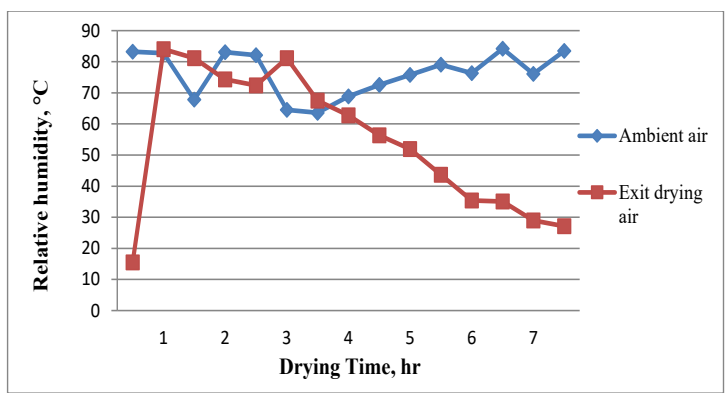

Figure 8. Relative humidity variations of ambient air and exit drying air

\section{Computed Drying Air Properties}

Other drying air properties such as humidity ratio and air enthalpy of drying air flue gas were computed. Likewise, flue properties were also analyzed. The results are shown in Table 2.

As shown in Table 2 , the ambient enthalpy $\left(h_{1}\right)$ is $90.72 \mathrm{~kJ} / \mathrm{kg}$, and the humidity ratio $\left(\mathrm{W}_{1}\right)$ is 0.0229 $\mathrm{kg} / \mathrm{kg}$. The value of air enthalpy $\left(\mathrm{h}_{2}\right)$ increased to $137.59 \mathrm{~kJ} / \mathrm{kg}$ immediately after passing the heat exchanger caused by the rapid rise in temperature. A fraction of thermal energy was utilized in water evaporation from the products as it passed through the drying chamber. It resulted in an increase of enthalpy at the exhaust with $\left(h_{3}\right)$ value of $259.33 \mathrm{~kJ} / \mathrm{kg}$. After leaving the drying chamber, the air humidity ratio $\left(\mathrm{W}_{3}\right)$ value has increased from $0.0229 \mathrm{~kg} / \mathrm{kg}$ to $0.0686 \mathrm{~kg} / \mathrm{kg}$, which means that there is only $0.0457 \mathrm{~kg} / \mathrm{kg}$ of moisture gained from the products. As in the case of flue gas, both its humidity and enthalpy have decreased from $0.0229 \mathrm{~kg} / \mathrm{kg}$ to $0.0216 \mathrm{~kg} / \mathrm{kg}$ to $276.20 \mathrm{~kJ} / \mathrm{kg}$ to $167.95 \mathrm{~kJ} / \mathrm{kg}$, respectively. The computed values of the volumetric airflow rate, specific volume, and air mass flow rate are also presented in Table 2 . The calculated water evaporation rate, which indicated the drying rate, is measured as $8.156 \mathrm{~kg} / \mathrm{hr}$. 
Table 2. Calculated thermodynamic properties at different points in the dryer set-up

\begin{tabular}{cccccccccc}
\hline Point & $\mathrm{T}_{\mathrm{db},}{ }^{0} \mathrm{C}$ & $\Theta, \%$ & $\mathrm{Pd}, \mathrm{kPa}$ & $\mathrm{Ps}, \mathrm{kPa}$ & $\mathrm{W}, \mathrm{kg} / \mathrm{kg}$ & $\mathrm{h}, \mathrm{kJ} / \mathrm{kg}$ & $\begin{array}{c}\mathrm{V}, \\
\mathrm{m}^{3} / \mathrm{hr}\end{array}$ & $\begin{array}{c}\mathrm{v}, \\
\mathrm{m}^{3} / \mathrm{kg}\end{array}$ & $\mathrm{m}, \mathrm{kg} / \mathrm{hr}$ \\
\hline Point 1 & 31.9 & 75.9 & 4.727 & 3.602 & 0.0229 & 90.72 & 192 & 0.895 & 214.43 \\
Point 2 & 76.7 & 3.6 & 41.401 & 1.470 & 0.0229 & 137.59 & 192 & 1.005 & 191.03 \\
Point 3 & 58.4 & 54.4 & 18.502 & 10.065 & 0.0686 & 259.33 & 186 & 1.042 & 178.47 \\
Point 4 & 210.9 & 2.5 & 1938.52 & 68.835 & 0.0229 & 276.20 & 288 & 4.274 & 67.38 \\
Point 5 & 108.9 & 2.5 & 138.49 & 3.407 & 0.0216 & 167.95 & 270 & 1.119 & 241.16 \\
\multicolumn{2}{l}{ Water evaporation rate } & & & & & & & & 8.156 \\
\hline
\end{tabular}

\section{Technical Performance of the Rice Hull-fueled Dryer}

The rice hull-fueled dryer's technical performance was measured in terms of its fuel consumption, thermal conversion efficiency, and drying air distribution inside the dryer, as described in the following sections:

\section{a. Fuel consumption}

Table 3. Fuel rate and total fuel consumption of the rice hull-fueled dryer

Table 3. Fuel Consumption Rate

\begin{tabular}{cccc}
\hline TRIAL & $\begin{array}{c}\text { TOTAL } \\
\text { FUEL } \\
\text { USED }(\mathrm{kg})\end{array}$ & $\begin{array}{c}\text { DRYING } \\
\text { TIME (hr) }\end{array}$ & $\begin{array}{c}\text { FUEL } \\
\text { CONSUMPTION } \\
\text { RATE (kg/hr) }\end{array}$ \\
\hline 1 & 68 & 6.50 & 10.46 \\
2 & 75 & 6.75 & 11.11 \\
3 & 78 & 6.50 & 12.00 \\
Average & 73.67 & 7.00 & 11.19 \\
\hline
\end{tabular}

The above results indicated that the average fuel consumption rate is $11.19 \mathrm{~kg} / \mathrm{hr}$ for an average drying time of 6.58 hours.

\section{b. Thermal Conversion Efficiency of the Rice Hull-fueled Dryer}

The computed thermal conversion efficiency (TCE) was very low, at $6.17 \%$. It resulted from great heat loss developed from the heat exchanger and the burner, where much of the flue gas was not sufficiently utilized. The type of temperature probe was not appropriate for measuring higher temperatures. It means that only $6.17 \%$ was converted to the thermal energy of the rice hull's heating value. These could be unburnt rice hull fuels included in discharging the ash at the furnace bottom (Boateng et al., 1992; Gan et al., 2018; Loy et al., 2018).

\section{c. Energy Use Efficiency}

Based on the heat transferred through the heat exchanger to the product, the energy use efficiency (EUE) was also low. Only $41.51 \%$ utilized the available energy from the furnace used in drying due to the low temperature drawn from the heat exchanger to the dryer (McNaughton, 1983). Therefore, only a very small amount of water vaporized per hour from the dried material.

d. Rice hull-Fueled Dryer Efficiency

The rice hull-fueled dryer efficiency obtained was only $11.79 \%$. The heat generated from the burner was poorly utilized. It means that the effective thermal energy used in evaporating water from the product was only $11.79 \%$ of available thermal energy from the drying air as drawn from the heat exchange. Therefore, only a slight amount of water was vaporized from the product. In order to increase this efficiency, there is 
a need to increase the drying air's residence time inside the chamber and lesser heat losses from the wall by insulation (Loy et al., 2018).

\section{Distribution of the Drying Air Temperature}

The drying air temperature distribution inside the drying chamber was determined every 30 minutes of the drying operation. Temperatures were separately gathered concerning location on the top, middle and bottom layer of the trays. The drying air temperature distribution data inside the drying chamber are shown and summarized in Figures 9 to 11. A half-hour temperature profile shows that the drying air generally follows similar trends, but more obvious to note is the apparent lower temperatures at the center point at all levels. The bottom layer generally has higher temperature profile than the top and middle layers.

During the preheating process of 60 minutes, the temperature inside the drying chamber has increased sharply, and uniformly distributed at different tray layers inside the drying chamber to a maximum mean temperature of $84.97^{\circ} \mathrm{C}$. One hour was found to be enough to have the desired temperature and the shelving of loaded trays to start the drying process. After loading within 30 minutes, the temperature fell to its lowest point in all tray locations. As seen in Figures 9 to 11, the bottom back right corner of the tray layer after six hours has reached $102.4^{\circ} \mathrm{C}$, and the middle center reached only $63.3^{\circ} \mathrm{C}$ as the lowest value. It signified the uneven distribution of air temperature, parallel to Erbay and Hepbasli (2014) findings. Thirty minutes after loading, the temperature distribution inside the drying chamber increasingly varied in almost all points within different locations' of the trays. Analysis of variance (ANOVA) with a $5 \%$ level of significance revealed a significant difference in drying air temperature distribution inside the drying chamber.

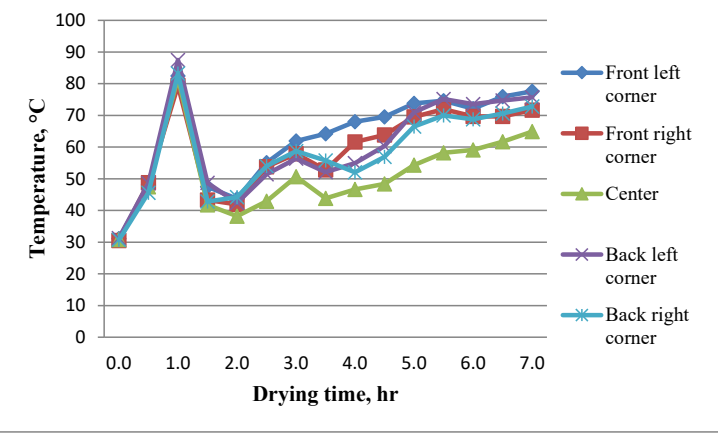

Figure 9. Profile of the drying air temperature, including preheating at the top tray layer No. 1

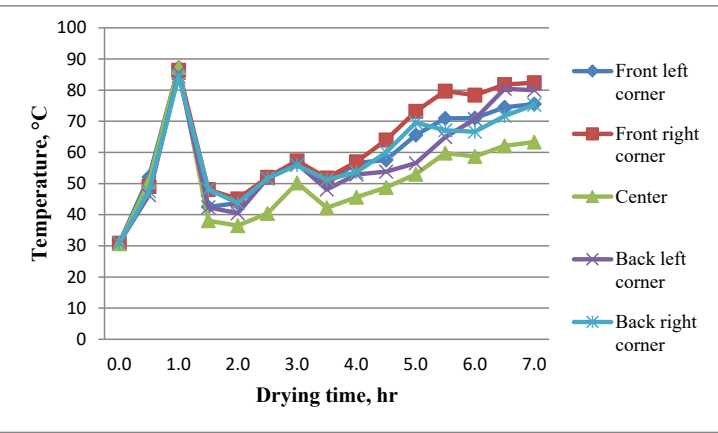

Figure 10. Profile of the drying air temperature, including preheating at the middle tray layer No. 6

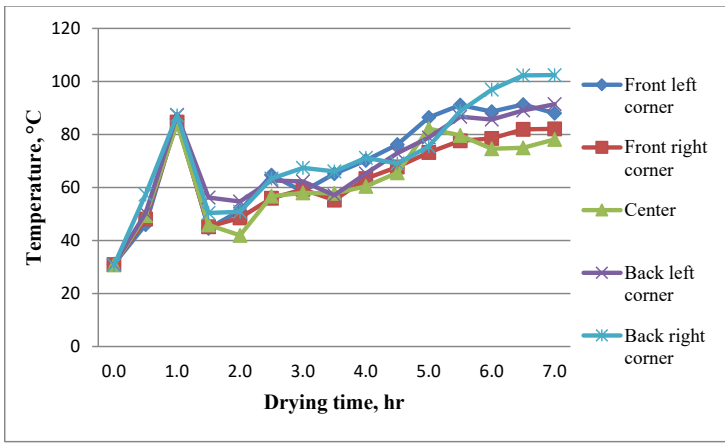

Figure 11. Profile of the drying air temperature, including preheating at the bottom tray layer No. 12

\section{Drying Characteristics of the Cassava Chips}

The cassava chips' drying characteristics are expressed in terms of the drying curves, 
instantaneous moisture content values, and the calculated drying rate values presented in the following sections.

\section{a. Sample Moisture Reduction}

The samples of about $100 \mathrm{~g}$ were placed in the four corners and in the center of each, located at the top layer No.1, middle tray layer No. 6 and bottom tray layer No.12 of the drying chamber, for the monitoring of moisture reduction every 30 minutes of drying operation. The mean instantaneous weight is summarized in Table 4.

Table 4. Mean instantaneous weight (g) of cassava chips

\begin{tabular}{ccccc}
\hline $\begin{array}{c}\text { DRYING } \\
\text { TIME, hr }\end{array}$ & $\begin{array}{c}\text { TOP } \\
(1)\end{array}$ & $\begin{array}{c}\text { MIDDLE } \\
(6)\end{array}$ & $\begin{array}{c}\text { BOTTOM } \\
(12)\end{array}$ & MEAN \\
\hline 0 & 102.61 & 99.77 & 107.53 & 103.30 \\
0.5 & 99.68 & 96.08 & 103.31 & 99.69 \\
1.0 & 96.75 & 92.38 & 99.09 & 96.08 \\
1.5 & 93.60 & 88.20 & 94.11 & 91.97 \\
2.0 & 90.45 & 84.01 & 89.14 & 87.87 \\
2.5 & 86.38 & 79.09 & 83.33 & 82.94 \\
3.0 & 82.32 & 74.17 & 77.53 & 78.01 \\
3.5 & 77.26 & 69.12 & 71.90 & 72.76 \\
4.0 & 72.21 & 64.08 & 66.28 & 67.52 \\
4.5 & 67.84 & 59.81 & 62.47 & 63.38 \\
5.0 & 63.47 & 55.55 & 58.67 & 59.23 \\
5.5 & 58.21 & 51.50 & 55.11 & 54.94 \\
6.0 & 52.96 & 47.46 & 51.55 & 50.66 \\
Oven dry & 36.24 & 34.63 & 39.66 & 36.84 \\
\hline
\end{tabular}

It is noticeable from the graph shown in Figure 12 that the curves are almost linear with a negative slope. It confirmed the results of the thermal analysis in which the relative humidity ratio values were used to determine the rate of water removed from the system. When the moisture gained 0.003 $\mathrm{kg} / \mathrm{kg}$, it was multiplied by the mass flow rate of $174.58 \mathrm{~kg} / \mathrm{hr}$, and obtained a $0.524 \mathrm{~kg} / \mathrm{hr}$ moisture reduction value. Relatively, the theoretical values would appear larger than the experimental values. However, their proximity signifies the fact that this method of evaluation proved its viability.

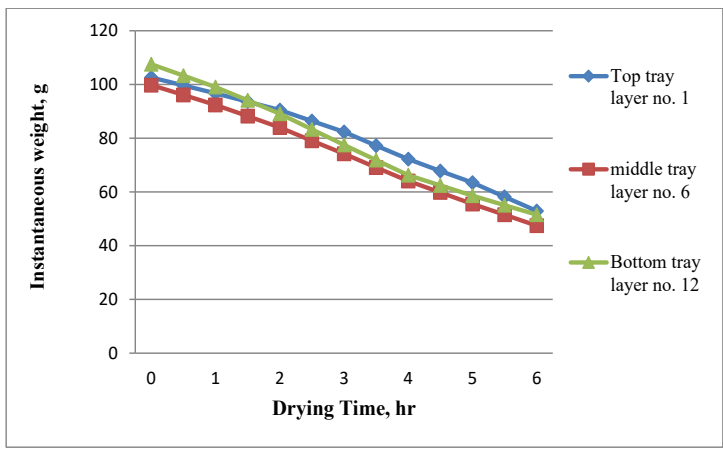

Figure 12. Mean of instantaneous weight $(g)$ of the cassava chips in different tray layers

\section{b. Instantaneous Moisture Content of the} Cassava Chips

The data for the cassava chips' instantaneous moisture content are shown and summarized in Table 5 and Figures 13 to 15 concerning the different tray layers.

Table 5. Mean of instantaneous moisture content (\%, dry basis) of the cassava chips

\begin{tabular}{ccccc}
\hline $\begin{array}{c}\text { DRYING } \\
\text { TIME, hr }\end{array}$ & TOP (1) & $\begin{array}{c}\text { MIDDLE } \\
(6)\end{array}$ & $\begin{array}{c}\text { BOTTOM } \\
(12)\end{array}$ & MEAN \\
\hline 0.0 & 185.16 & 185.14 & 184.70 & 185.00 \\
0.5 & 176.98 & 174.41 & 172.68 & 174.69 \\
1.0 & 168.51 & 163.65 & 161.53 & 164.56 \\
1.5 & 159.59 & 151.47 & 148.30 & 153.12 \\
2.0 & 150.68 & 139.27 & 135.06 & 141.67 \\
2.5 & 138.98 & 125.02 & 119.53 & 127.84 \\
3.0 & 127.27 & 110.74 & 103.99 & 114.00 \\
3.5 & 112.88 & 96.18 & 89.78 & 99.61 \\
4.0 & 98.48 & 81.61 & 76.32 & 85.47 \\
4.5 & 86.22 & 69.52 & 65.89 & 73.88 \\
5.0 & 73.95 & 57.44 & 55.32 & 62.24 \\
5.5 & 59.72 & 46.18 & 45.52 & 50.47 \\
6.0 & 45.49 & 34.92 & 35.82 & 38.74 \\
\hline
\end{tabular}




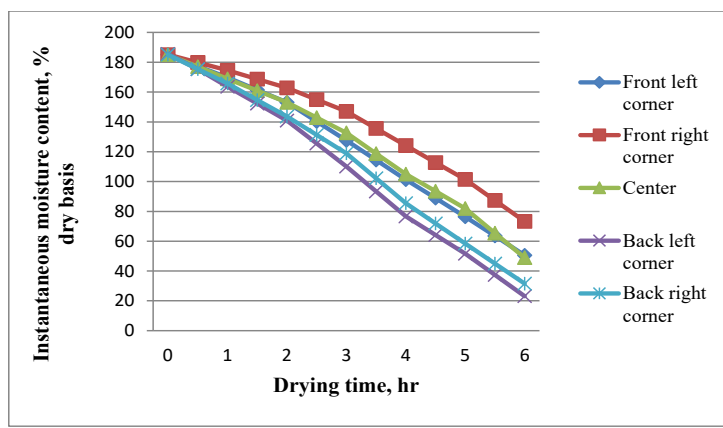

Figure 13. Instantaneous moisture content of the cassava chips at the top tray layer No. 1

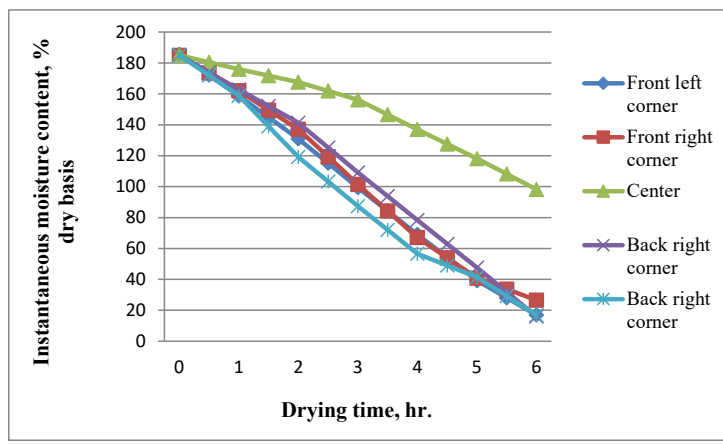

Figure 14. The instantaneous moisture content of the cassava chips at the middle tray layer No. 6

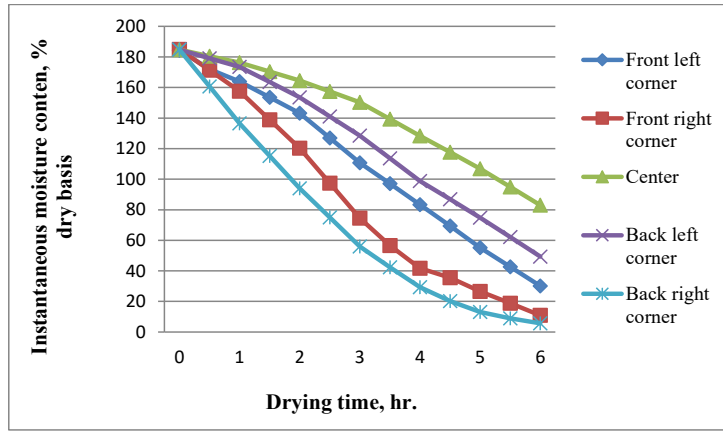

Figure 15. The instantaneous moisture content of the cassava chips at the bottom tray layer No. 12

The moisture reduction of the samples in the top tray layer No. 1 shows a different pattern than tray layer No. 6 and No. 12. The behavior of moisture reduction at the top layer is slower at the start. It became faster at a later time in the drying process. This is the effect of the uneven distribution of drying air temperature. The drying behavior of samples at the center of tray layer No. 6 and No. 12 are generally slower as earlier manifested of lower air temperature received. To address this slow drying process, the drying air in the chamber must be stirred, or the products in each tray should be stirred periodically. However, instantaneous moisture contents of tray layer No. 12 followed a sharp fall at the start then slows down at the later drying time. It is also explained by the occurrence of higher drying air temperatures that the layer received. Right wall products also have higher moisture reduction rates compared to those nearer the left wall.

The samples' instantaneous moisture content was analyzed and compared concerning tray points of samples within trays. Based on the analysis of variance (ANOVA) using a $5 \%$ level of significance, there is a highly significant difference concerning the tray point, but no significant difference concerning the tray layers. It means that the samples' instantaneous moisture content differs concerning tray points of sampling within tray layers (top, middle and bottom) inside the drying chamber.

\section{c. Rate of Moisture Removal}

Drying rate is the rate of moisture removed from the sample on the actual duration of the drying process. The computed drying rate of the cassava chips is summarized in Table 6, and the different tray layers such as top, middle and bottom are illustrated in Figures 16 to 18. The computed moisture reduction rate is $8.156 \mathrm{~kg} / \mathrm{hr}$ based on the obtained data. 
Table 6. Mean computed drying rate of the cassava chips

\begin{tabular}{ccccc}
\hline $\begin{array}{c}\text { DRYING } \\
\text { TIME, hr }\end{array}$ & TOP (1) & $\begin{array}{c}\text { MIDDLE } \\
(6)\end{array}$ & $\begin{array}{c}\text { BOTTOM } \\
(12)\end{array}$ & MEAN \\
\hline 0.5 & 16.37 & 21.47 & 24.02 & 20.62 \\
1.0 & 8.47 & 10.75 & 11.16 & 10.13 \\
1.5 & 5.94 & 8.12 & 8.82 & 7.63 \\
2.0 & 4.46 & 6.10 & 6.62 & 5.73 \\
2.5 & 4.68 & 5.70 & 6.21 & 5.53 \\
3.0 & 3.90 & 4.76 & 5.18 & 4.61 \\
3.5 & 4.11 & 4.16 & 4.06 & 4.11 \\
4.0 & 3.60 & 3.64 & 3.37 & 3.54 \\
4.5 & 2.72 & 2.69 & 2.32 & 2.58 \\
5.0 & 2.45 & 2.42 & 2.12 & 2.33 \\
5.5 & 2.59 & 2.05 & 1.78 & 2.14 \\
6.0 & 2.37 & 1.88 & 1.62 & 1.96 \\
\hline
\end{tabular}

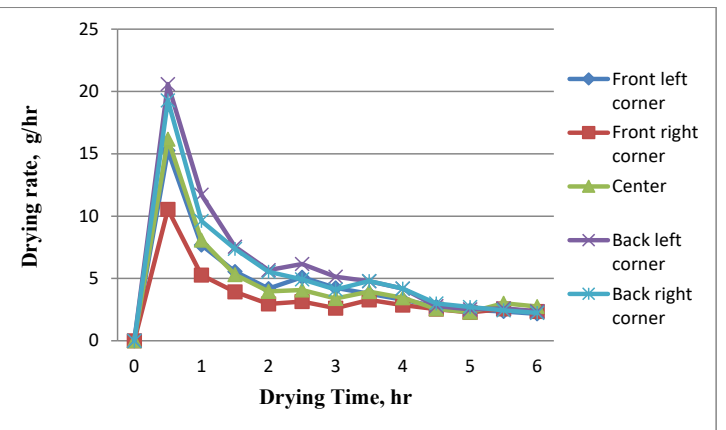

Figure 16. Profile of the drying rate of top tray layer No. 1

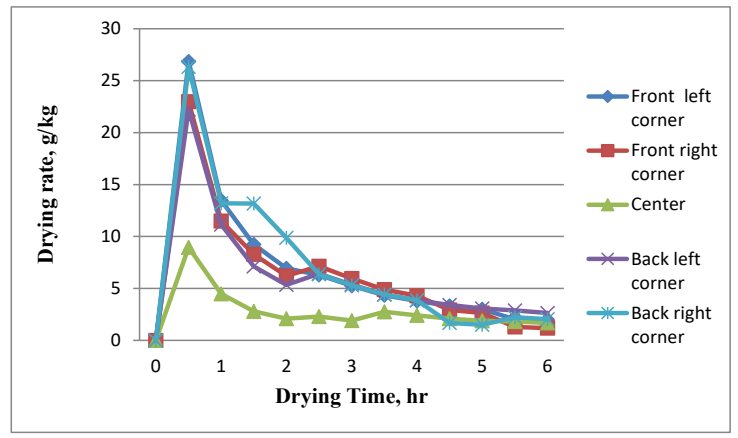

Figure 17. Profile of the drying rate of middle tray layer No. 6

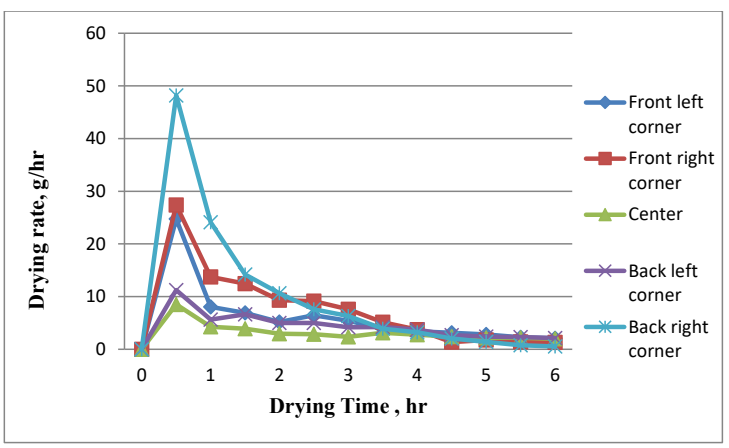

Figure 18. Profile of the drying rate at the bottom tray layer No. 12

The drying rate of the sample at different tray layers was fluctuating. However, it was decreasing from the start of the drying until the end of the process. It means that the rate of moisture removal of the sample at the top, middle and bottom layers of the trays was not constant. The cassava chips' drying rates are not significantly different from tray points and within the tray layer by analysis of variance (ANOVA). This means the samples' drying rates statistically do not differ concerning tray layers and points. Figures 16 to 18 show the average drying rate of the samples of different tray layers. The samples at the bottom tray layer No. 12 have a faster drying rate with an average value of 10.34 $\mathrm{kg} / \mathrm{hr}$ for the first three hours of drying operation. The middle tray (6) and top tray (1) have an average value of $9.48 \mathrm{~kg} / \mathrm{hr}$ and $7.30 \mathrm{~kg} / \mathrm{hr}$. It implied that the product at the bottom portion drying chamber dried faster than the top portion of the drying chamber (Adapa et al., 2002; Eze, 2010).

\section{Cost Analysis in Using the Rice Hull-Fueled Dryer}

The cost of using a rice hull-fueled dryer was determined using the break-even cost analysis and return analysis in computing the drying cost. The break-even cost computations of operating the dryer obtained the amount of $P 4.988 / \mathrm{kg}$ of cassava chips. Drying cost includes all the expenses 
incurred using the machine, rice hull fuel, power and labor. The payback period of using the rice hull-fueled dryer is 0.988 year. It means that the rice hull-fueled dryer is much cheaper compared to other dryers. Hence, aside from environmentally friendly, rice hull as biomass fuel is economical (Winzer et al., 2017). Table 7 shows the cost and return analysis of using the dryer.

Table 7. Cost and return and return analysis of using the rice hull-fueled dryer

\begin{tabular}{|c|c|}
\hline \multicolumn{2}{|l|}{ Cost and Return Analysis } \\
\hline A. Assumptions: & B. Return/income \\
\hline Machine Acquisition Cost $=\mathbb{P} 132,000$ & $76 \mathrm{~kg}$ at at $P 10.00$ per kg \\
\hline \multicolumn{2}{|l|}{ Life Span $=5$ years } \\
\hline Salvage Value $=10 \%$ of MAC & Profit $=$ P 400.84/batch \\
\hline Depreciation $=\mathbb{P} 23,000$ & Hourly Total Cost $=尹 59.86 / \mathrm{kg}$ \\
\hline Repair and Maintenance Cost $=10 \%$ of MAC & Break-Even $=P 4.988 / \mathrm{kg}$ \\
\hline Labor Requirement $=2$ man-days & Profit $=P 760 /$ batch \\
\hline Labor cost $=P 250 /$ day & Payback Period $=0.988$ year \\
\hline \multicolumn{2}{|l|}{ Operating Time $=8 \mathrm{hrs} /$ day } \\
\hline \multicolumn{2}{|l|}{ Operating days $/$ month $=25$ days $/ \mathrm{mon}$} \\
\hline \multicolumn{2}{|l|}{ Operating month/year = 10 mon/yr } \\
\hline \multicolumn{2}{|l|}{ Power Requirement $=1-1 \mathrm{hp}-$ motor } \\
\hline \multicolumn{2}{|l|}{ Power Cost $=$ P 4.8/kW-hr } \\
\hline Dryer Capacity $=12$ tray at $18 \mathrm{~kg} / \mathrm{m} 2$ & \\
\hline
\end{tabular}

\subsection{Conclusion}

This study aims to evaluate the performance and economic aspect of a rice hull-fueled cabinet food dryer. The experiment results showed that the drying performance (instantaneous weight of the sample, instantaneous moisture content and drying rate) of the rice hull-fueled dryer is highly affected by drying air temperature distribution, wherein points of high temperature has a faster rate of water removal for the products. It implies that the dryer's drying performance is not thoroughly equitable for good control of temperature and moisture removal from the products. To increase the $6.17 \%$ thermal conversion efficiency and $41.51 \%$ energy use efficiency, the furnace and heat exchanger unit's design must be modified and improved. Hence, one must employ an automated or improved feeding mechanism for rice hull fed to the furnace to ensure uniform flue gas temperature supply. Also, the experiment showed that only a slight amount of water was vaporized from the cassava chips. Therefore, it is concluded that to increase the dryer's efficiency, there is a need to increase the residence time of the drying air inside the chamber and lessen the heat loss from the wall by the insulation process. Furthermore, it is revealed that the mechanical dryer cost is very affordable compared to other existing food dryer.

\section{References}

Adapa, P. K, Sokhansanj, S., \& Schoenau, G. J. (2002). Performance study of a re-circulating cabinet dryer using a household dehumidifier. Drying 
Technology: An International Journal, 20(8), 1673-1689. https://doi.org/10.1081/DRT120015407

Boateng, A. A., Walawender, W. P., Fan, L. T., \& Chee, C. S. (1992). Fluidized-bed steam gasification of rice hull. Bioresource Technology, 40(3), 235-239. https://doi.org/10.1016/09608524(92)90148-Q

Brennan, J. G., Butters, J. R., Cowelli, N. D., \& Lilly, A. E. V. (1976). Food engineering operations (2nd ed.). Applied Science Publishers Limited.

Descoteaux, S., \& Savoie, P. (2003, July 6-9). Development and evaluation of a dryer for big square hay bales [Paper presentation]. Canadian Society for Engineering in Agricultural, Food, and Biological Systems/ La Societe Canadienne de Genie Agroalimentaire et Biologique 2003 Meeting, Montreal Quebec. file:///C:/Users/ imcmain/Downloads/DEVELOPMENT_AND_ EVALUATION_OF_A_DDRYE_FOR_BIG_SQUA. pdf

Erbay, Z., \& Hepbasli, A. (2014). Advanced exergoeconomic evaluation of a heat pump food dryer. Biosystems Engineering, 124, 29-39. https://doi.org/10.1016/j. biosystemseng.2014.06.008

Erbay, Z., \& Hepbasli, A. (2017). Exergoeconomic evaluation of a ground-source heat pump food dryer at varying dead state temperatures. Journal of Cleaner Production, 142, 1425-1435. https://doi.org/10.1016/j.jclepro.2016.11.164

Eze, J. I. (2010). Evaluation of the efficacy of a family sized solar cabinet dryer in food preservation. American Journal of Scientific and Industrial Research, 1(3), 610-617. 10.5251/ajsir.2010.1.3.610.617

Gan, D. K. W., Loy, A. C. M., Chin, B. L. F., Yusup, S., Unrean, P., Rianawati, E., \& Acda, M. N. (2018). Kinetics and thermodynamic analysis in onepot pyrolysis of rice hull using renewable calcium oxide-based catalysts. Bioresource Technology, 265, 180-190. https://doi. org/10.1016/j.biortech.2018.06.003

Gatea, A. A. (2010). Design, construction and performance evaluation of solar maize dryer. Journal of Agricultural Biotechnology and Sustainable Development, 2(3), 39-46. https:// academicjournals.org/journal/JABSD/articlefull-text-pdf/4842C16588

Iranmanesh, M., Akhijahani, H. S., \& Jahromi, M. S. B. (2020). CFD modeling and evaluation the performance of a solar cabinet dryer equipped with evacuated tube solar collector and thermal storage system. Renewable Energy, 145, 1192-1213. https://doi.org/10.1016/j. renene.2019.06.038

Liu, Y., Guo, F., Li, X., Li, T., Peng, K., Guo, C., \& Chang J. (2017). Catalytic effect of iron and nickel on gas formation from fast biomass pyrolysis in a micro fluidized bed reactor: A kinetic study. Energy Fuels, 31(11), 12278-12287. https://doi. org/10.1021/acs.energyfuels.7b02214

Loy, A. C. M., Gan, D. K. W., Yusup, S., Chin, B. L. F., Lam, M. K., Shahbaz, M., Unrean, P., Acda, M N., \& Rianawati, E. (2018). Thermogravimetric kinetic modelling of in-situ catalytic pyrolytic conversion of rice husk to bioenergy using rice hull ash catalyst. Bioresource Technology, 261, 213-222. https://doi.org/10.1016/j. biortech.2018.04.020 
Luh, E. P. (1980). Rice production and utilization. AVI Publishing Company.

McNaughton, A. (1983). Report of a seminar on energy conservation in food processing industries [Manuscript reports]. International Development Research Center. https://idl-bncidrc.dspacedirect.org/handle/10625/7048

Pardhi, C. B., \& Bhagoria, J. L. (2013). Development and performance evaluation of mixedmode solar dryer with forced convection. International Journal of Energy and Environmental Engineering, 4(23). https://doi. org/10.1186/2251-6832-4-23

Smith, D. W., Sims, B. G., \& O'neil, D. H. (1994). Testing and evaluation of agricultural machinery and equipment: Principles and practices. Publications Division, Food and Agriculture Organization of the United Nations. http:// www.fao.org/3/t1841e/t1841e.pdf

Valchev, I., Lasheva, V., Tzolov, T., \& Josifov, N. (2009). Silica products from rice hulls. Journal of the University of Chemical Technology and Metallurgy, 44(3), 257-261. https://dl.uctm.edu/ journal/node/j2009-3/7_Lasheva_257-261.pdf

Winzer, F., Kraska, T., Elsenberger, C., Kötter, T., \& Pude, R. (2017). Biomass from fruit trees for combined energy and food production. Biomass and Bioenergy, 107, 279-286. https:// doi.org/10.1016/j.biombioe.2017.10.027 